\title{
Nursing intervention/activity mapping at a Chemotherapy Center: an instrument for workload assessment ${ }^{1}$
}

\author{
Célia Alves de Souza ${ }^{2}$ \\ Marli de Carvalho Jericó ${ }^{3}$ \\ Márcia Galan Perroca ${ }^{3}$
}

\begin{abstract}
Objectives: identify the interventions/activities nurses develop at a Chemotherapy Center (CTC) using standardized language and validate their contents. Method: data triangulation was used through the combination of three information sources: semistructured interview, document analysis and questionnaire. The instrument, constructed in accordance with the Nursing Interventions Classification (NIC) taxonomy, was submitted to content validation through meetings with the participants. Results: Thirty-five interventions and 48 activities were mapped and validated, organized in five domains (physiological: basic and physiological: complex, behavioral, safety and health system) and 11 classes. Conclusion: The identification of nurses' interventions/activities at CTC supports the determination of the time consumed and permits measuring the workload. It also helps to define these professionals' role, which permits the redesign of the work process and optimizes productivity.
\end{abstract}

Descriptors: Workload; Oncology Nursing; Chemotherapy; Nursing Staff at the Hospital; Nursing Care.

\footnotetext{
${ }^{1}$ Supported by Faculdade de Medicina de São José do Rio Preto, process \# 4331/2010.

2 Master's student, Faculdade de Medicina de São José do Rio Preto, São José do Rio Preto, SP, Brazil. Assistant Professor, Faculdade de Medicina de São José do Rio Preto, São José do Rio Preto, SP, Brazil.

${ }^{3}$ PhD, Professor, Faculdade de Medicina de São José do Rio Preto, São José do Rio Preto, SP, Brazil.
} 


\section{Introduction}

Workload refers to all activities the team accomplishes over a certain period in the care process and the time spent to perform these actions ${ }^{(1)}$. Nursing workload measurement research usually involves two parts: the identification and listing of activities and the measuring of the time consumed. The information produced enables nurse managers to identify the team's care functions, supporting staff dimensioning(2); pictures the work flow and the work process(3), permitting its redesign when necessary, and also help to seek strategies to improve productivity and care quality(3)

The term nursing intervention designates any treatment based on nurses' clinical judgment and knowledge to enhance patient/client outcomes ${ }^{(4)}$. Each intervention is detailed in a range of activities. The activity shows what a person does in the organization, relating to ${ }^{(4)}$ the behaviors or specific actions nurses perform to put in practice an intervention and help patients to achieve the desired result.

One of the oldest first known studies of nursing activities was published in the United States in 1934, listing 738 items $^{(5)}$. Since then, the increased complexity of patient care and the technological development and consolidation of nursing as a science have caused changes and led to the expansion of activities.

In 1992, a group of researchers from the University of Iowa College of Nursing, in the United States, published the Nursing Interventions Classification (NIC), with a view to standardizing the language nurses use to describe specific care conducts and permit comparisons among care in different contexts ${ }^{(4)}$. In subsequent years, the taxonomic structure was revised and updated to include new interventions. In the most recent version ${ }^{(4)}$, 514 interventions are described, organized in seven domains (physiological: basic, physiological: complex, behavioral, safety, family, health system and community) and thirty classes. Each intervention consists of a set of related activities, totaling more than 12,000 activity descriptions.

Time management at work is considered a vital resource in organizations to improve processes and productivity(6). Brazilian and international literature contains different studies on nursing team time distribution. Some of these are mainly focused on mapping activities and checking their frequency ${ }^{(7)}$; others are focused on the elaboration of an activity classification instrument(6). Yet others address nursing work time management, using different measurement methods in scenarios like the medical $\operatorname{clinic}^{(8)}$, medicalsurgical unit( ${ }^{(9)}$, rooming in ${ }^{(10)}$, emergency unit(11), telemetry unit(5), among others. The use of the NIC as a model to develop nursing workload measures has been important in the literature(12).

Despite significant scientific production on the time factor in nursing work, however, few studies have been developed at oncology outpatient clinics, and more specifically at Chemotherapy Centers (CTC). The use of the work sampling method is discussed in an Australian study to determine the functions performed and nurses' workload in hematology and outpatient radiotherapy ${ }^{(13)}$. An experience report on the adaptation of available instruments for productivity measurement at an oncology outpatient clinic has also been described in an American study ${ }^{(14)}$

The aim in this research was to identify the interventions/activities nurses developed at a Chemotherapy Center, using standardized language, and to validate their contents.

\section{Method}

\section{Design}

Data triangulation was used to identify the activities nurses develop in the application of outpatient chemotherapy. This method involves the use of multiple data sources to obtain different foci on the same phenomenon ${ }^{(15)}$. Triangulation was obtained through the combination of three information sources: 1 semistructured interview; 2 . document analysis and 3 . questionnaire.

The context selected for this study was a Chemotherapy Center at a large hospital that predominantly attends to Unified Health System (SUS) users. The institution is a Level II High-Complexity Oncology Center (CACON II) and considered a referral institution for care delivery to oncology patients in São Paulo State.

The Chemotherapy Center attends to about 3,700 people and infuses 9,400 drugs per month. The multiprofessional team consists of ten physicians, ten baccalaureate nurses (nine clinical and one supervisor), seven nursing technicians, five nursing assistants and five pharmacists. Care is delivered in six rooms, distributed as follows: rooms 1 and 2 for bedridden patients ( 20 beds), rooms 3 and 4 for female patients (30 armchairs) and rooms 5 and 6 for male patients (26 armchairs). 
Study participants were nine clinical nurses who worked at the research unit at the time of data collection, that is, between May and July 2010. Most professionals were female $(n=7)$, with a mean age of 29 years $(S D=5)$ (range 24-41), mean professional experience of five years $(S D=1)$ (range 5-14) and two years of CTC experience $(S D=1.4)$ (range 1-5). As regards professional qualification, seven participants were cancer nursing specialists and the other two were taking the same specialization program.

\section{Information sources}

Interview

To initially address the theme, semistructured interviews were held with nurses working at four chemotherapy outpatient units (three private and one public) in other than the main research context. This exploratory research was aimed at identifying, through their discourse, the interventions/activities performed in their work process (list 1). Data were collected between August and November 2009 by a cancer nursing student.

Document analysis

At the CTC where the main research was undertaken, nursing notes were consulted in the patient files. After careful reading, interventions/activities were identified, compiled and organized according to the nursing language (list 2).

Application of the Questionnaire

A two-part instrument was used, in combination with a letter in which the study objectives were explained. The first part contained information about the participants' personal and professional characteristics. In the second, the nurses working at the CTC where the main research was undertaken were asked to list all activities and interventions they performed in their daily work, whether directly related to the patient or not (list 3).

\section{Ethical Aspects}

Before data collection, the project was submitted to the Institutional Review Board of the institution where the study was accomplished (opinion 290/2010) and the nurses participated after signing the informed consent form.

\section{Data Collection Procedure}

Instrument construction

The interventions/activities obtained from the interviews with the nurses at different chemotherapy centers (list 1 ), consultation of patient files (list 2) and those the nurses described in the questionnaires (list 3) were combined in a single list. Then, similar interventions/activities were grouped and repeated ones were removed. The Nursing Interventions Classification (NIC) $)^{(4)}$ was used a theoreticalmethodological framework in this study. The terms the nurses used to describe the activities they performed were aligned with this taxonomy and fit into the most pertinent domains and classes. Those interventions/activities that did not correspond to the NIC nomenclature were considered as activities associated with nursing work and personal activities. Associated activities are considered as activities that do not need to be practiced by a nursing professional, and personal activities as work pauses to attend to physiological and rest needs ${ }^{(16)}$.

Instrument validation

The instrument was elaborated in standardized language and then submitted to content validation ${ }^{(15)}$ to check whether the activities mapped were relevant to and representative of the CTC nurses' care practice. Two four-hour meetings were held with nine clinical nurses who participated in the main research. The intent was to evaluate the items proposed in the instrument, in search of a consensus on their pertinence. On that occasion, doubts were clarified about some activity names. Interventions/activities with $100 \%$ of agreement were considered as validated.

\section{Data presentation and treatment}

The collected data were treated using descriptive statistics and presented as frequencies, means and standard deviations.

\section{Results}

\section{Instrument construction}

During the interviews with the nurses at different chemotherapy centers, 26 activities were mentioned, including direct and indirect care and organizationrelated and educative activities. 
The consultation of nursing care records in the files of patients submitted to antineoplastic therapy permitted the identification of nursing activities like intravenous insertion, medication administration, admission care, interpretation of laboratory results, among others. The lists the nurses provided through the questionnaire resulted in 166 items that, when grouped according to similarity, totaled 48 activities.

\section{Validation}

The nurses submitted the instrument, which contained the domains, classes, interventions and activities that resulted from the grouping of the previous research phases, to content validation. The participants suggested dismembering or excluding some activities or including others. Thus, in its final version, the instrument consisted of 35 interventions and 48 activities, organized in five domains (physiological: basic, physiological complex, behavioral, safety and health system) and 11 classes and activities associated with nursing work and personal activities (Figures 1, 2 and 3). Nine activities were identified in the "Physiological: basic" domain, thirteen in the "Physiological: complex", one in "Behavioral", six in "Safety" and nineteen in "Health System". Personal activities included pauses for meals and response to physiological needs.

\begin{tabular}{|c|c|c|}
\hline \multicolumn{3}{|c|}{ Physiological: Basic Domain } \\
\hline Class & Intervention & Activity \\
\hline B- Elimination management & 580 Urinary catheterization & Install intermittent/permanent urinary tube \\
\hline \multirow{3}{*}{ D- Nutrition support } & 1080 Gastrointestinal intubation & (Help to) install gastrointestinal tube \\
\hline & 1874 Tube care: gastrointestinal & Forward patient to X-ray (positioning) \\
\hline & 1056 Enteral tube feeding & $\begin{array}{l}\text { Delivering nutrients and water through a } \\
\text { gastrointestinal tube }\end{array}$ \\
\hline \multirow{5}{*}{ E- Physical comfort promotion } & 1400 Pain management & Assess the patient's pain (pain scale) \\
\hline & \multirow{3}{*}{6482 Environmental management: comfort } & Adjust environmental temperature \\
\hline & & Provide for or remove blankets \\
\hline & & $\begin{array}{l}\text { Use screens or close curtains to preserve the } \\
\text { patient's privacy }\end{array}$ \\
\hline & 1570 Vomiting management & $\begin{array}{l}\text { Control for environmental factors capable of } \\
\text { causing vomiting }\end{array}$ \\
\hline \multicolumn{3}{|c|}{ Physiological: Complex Domain } \\
\hline \multirow{6}{*}{$\mathrm{H}$ - Drug management } & 2304 Medication administration: oral & Give medication through the oral route (OR) \\
\hline & 2314 Medication administration: intravenous & Give intravenous medication (IV) \\
\hline & 2313 Medication administration: intramuscular & Give intramuscular medication (IM) \\
\hline & 2317 Medication administration: subcutaneous & Give subcutaneous medication (SC) \\
\hline & 2380 Medication management & $\begin{array}{l}\text { Deliver medication for oral administration } \\
(\mathrm{OR}) \text { and provide information on its use }\end{array}$ \\
\hline & 2240 Chemotherapy management & $\begin{array}{l}\text { Offer patients and families information about } \\
\text { the action of antineoplastic agents }\end{array}$ \\
\hline \multirow{7}{*}{$\begin{array}{l}\mathrm{N} \text {-Tissue perfusion } \\
\text { management }\end{array}$} & \multirow{2}{*}{4190 Intravenous insertion } & Install peripheral venous access \\
\hline & & Remove venous access \\
\hline & 4238 Phlebotomy: venous blood sample & Collect blood sample for laboratory tests \\
\hline & \multirow{4}{*}{2440 Venous access device maintenance } & Prepare material for venous access \\
\hline & & Puncture tunneled central venous catheter \\
\hline & & $\begin{array}{l}\text { Maintain permeability using saline solution } \\
\text { and/or heparin }\end{array}$ \\
\hline & & $\begin{array}{l}\text { Make notes on catheter insertion } \\
\text { maintenance }\end{array}$ \\
\hline
\end{tabular}

Figure 1 - Interventions/activities identified by CTC nurses in basic and complex physiological domains. Barretos, SP, Brazil, 2010 


\begin{tabular}{|c|c|c|}
\hline \multicolumn{3}{|c|}{ Health System Domain } \\
\hline Class & Intervention & Activity \\
\hline \multirow{10}{*}{$\begin{array}{l}\text { A-Health system } \\
\text { management }\end{array}$} & \multirow[b]{2}{*}{7310 Admission care } & Complete patient identification form \\
\hline & & $\begin{array}{l}\text { Identify patient with fever and start critical path for febrile } \\
\text { neutropenia }\end{array}$ \\
\hline & \multirow{2}{*}{7640 Critical path development } & Apply drug extravasation pathway \\
\hline & & Perform screening \\
\hline & 7660 Emergency cart checking & Check and replace emergency cart items \\
\hline & 7690 Laboratory data interpretation & Analyze laboratory results before $\mathrm{CT}$ and hormone therapy \\
\hline & 7710 Physician support & Schedule emergency tests upon medical prescription \\
\hline & 7800 Quality monitoring & Collect data for the elaboration of quality indicators \\
\hline & 7830 Staff supervision & Elaborate activity distribution scale for technicians \\
\hline & 7840 Supply management & Type daily material order \\
\hline \multirow{9}{*}{ B-Information management } & \multirow[b]{2}{*}{7910 Consultation } & Visit the lodging "Madre Paulina" \\
\hline & & $\begin{array}{l}\text { Collect data and identify the problem focused on in the } \\
\text { consultation }\end{array}$ \\
\hline & 7920 Documentation & Make nursing notes in patient's file \\
\hline & 7980 Incident reporting & $\begin{array}{l}\text { Identify and notify adverse reactions/events, anomalies and } \\
\text { non-conformities }\end{array}$ \\
\hline & 8100 Referral & Forward patient for hospitalization \\
\hline & \multirow{2}{*}{8140 Shift report } & Provide information about patient to medical team \\
\hline & & Transmit/receive nursing team shift \\
\hline & \multirow{2}{*}{8180 Telephone consultation } & Register telephone orientation \\
\hline & & Orient outpatient by phone \\
\hline
\end{tabular}

Figure 2 - Interventions/activities identified by CTC nurses in the health system domain. Barretos, SP, Brazil, 2010

\begin{tabular}{|c|c|c|}
\hline \multicolumn{3}{|c|}{ Behavioral Domain } \\
\hline Class & Intervention & Activity \\
\hline R-Coping assistance & 5420 Spiritual support & Listen and provide therapeutic support to patient and family \\
\hline \multicolumn{3}{|c|}{ Safety Domain } \\
\hline \multirow{3}{*}{ S-Patient education } & \multirow{3}{*}{5618 Teaching: procedure/treatment } & Orient patient and family about procedures and treatment. \\
\hline & & Orient non-febrile neutropenic patients about infection prevention \\
\hline & & $\begin{array}{l}\text { Orient patient/family about extravasation and provide folder with } \\
\text { explanations }\end{array}$ \\
\hline U-Crisis management & 6200 Emergency care & (Help to) perform cardiopulmonary resuscitation \\
\hline \multirow[t]{2}{*}{ V-Risk management } & 6680 Vital signs monitoring & $\begin{array}{l}\text { Check blood pressure, pulse, body temperature and breathing } \\
\text { pattern }\end{array}$ \\
\hline & 6650 Surveillance & Check and monitor patient in hospital system (sishop) \\
\hline
\end{tabular}

Figure 3 - Interventions/activities identified by CTC nurses in the behavioral and safety domains. Barretos, SP, Brazil, 2010

\section{Discussion}

This study intended to identify and validate the interventions/activities nurses performed in outpatient chemotherapy. With a view to greater accuracy, different information sources were used (interview document analysis and questionnaire) in different contexts.

Although many researchers have constructed instruments as the initial phase in time allocation studies, few of them have explained how these were developed. Some reports refer to elaboration based on brainstorming with the nursing team ${ }^{(13)}$, a computer list from a hospital management system ${ }^{(5)}$, patient file records and direct care observation ${ }^{(10-11)}$ and self-report by nurses working at the unit ${ }^{(9)}$. Others are based on a literature review and researchers' professional experiences $^{(6)}$ or culturally adapt instruments available in the literature(8).

The number of activities produced in these lists varies. A study developed at radiotherapy and onco- 
hematology units found 24 direct and 26 indirect care activities $^{(13)}$; at a telemetry unit -22 activities $^{(5)}$ and at medical clinics ${ }^{(9)} 25$ items. None of those instruments specifically addresses nurses' activities at Chemotherapy Centers though, making comparisons with the 48 activities identified in this study difficult.

Among different cancer treatment modalities, chemotherapy is perhaps the one that most affects patients' psychobiological and social aspects, due to the reactions the drugs cause. Technological advances in the pharmaceutical industry led to the inclusion of a range of antineoplastic drugs in the market, demanding new clinical pathways to attend to these clients' needs ${ }^{(17)}$.

The complexity of chemotherapy has required new competences from cancer nurses. According to Federal Nursing Council (COFEN) Resolution 210/98(18), these involve: planning, organizing, supervising and executing nursing activities during treatment; elaborating clinical pathways for the prevention, treatment and minimization of side effects and disseminating risk and problem prevention measures through patient/family education. Through its publications, the Instituto Nacional do Câncer (INCA) has also emphasize nursing actions for cancer prevention and control(19).

Based on these study findings, it was observed that most interventions/activities were related to the "Physiological: Complex" and "Health System" domains. In the "Medication Management" class of the Physiological: Complex domain, the predominant activities were related to medication administration through different routes, particularly intravenous, which demands technical skills from nurses when applying irritant or vesicant drugs. Venous access care activities are prophylactic recommendation with a view to patients' safety, related to infection and drug extravasation, which can cause important damage(20-21), as they provoke severe irritation, including vesicle formation and tissue destruction when infiltrated outside blood vessels ${ }^{(21-22)}$.

Therefore, tissue perfusion management (interventions to improve blood and fluid circulation in tissue) ${ }^{(4)}$ at the Chemotherapy Center is a source of concern in clinical nursing practice. Risk factors for extravasation are related to cutaneous vascular fragility, common in this patient group, caused by nutritional shortages; to the sclerosing and irritant action of antineoplastic drugs and to the progressive weathering of the peripheral venous network, blood transfusion, application of contrasts for tests and thrombocytopenia(22). Activities for this group require skills from nurses to select the best intravenous insertion site. In addition, to guarantee safer application of antineoplastic drugs, it is important to use indwelling venous catheters, whose insertion and maintenance are nurses' exclusive activity(19).

Chemotherapy management, which the NIC considers as activities that explain the administration process of chemotherapeutic agents and their adverse effects, evidences the need to orient patients and family members on how to manage or minimize the effects deriving from treatment ${ }^{(17)}$, among which nausea stands out. The importance of this orientation is also emphasized in other studies developed based on nursing

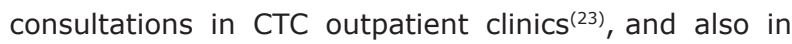
counseling and education activities ${ }^{(14,17)}$. Hence, cancer nurses play an important role in the education and information of chemotherapy patients ${ }^{(13,17)}$.

Among the activities listed in the "Health System" domain, the intervention "interpretation of laboratory data" before chemotherapy is highlighted, which requires knowledge and skills from nurses to use this information for clinical decision making on whether to release the chemotherapy or not.

Literature findings show that nurses play an important role in the assessment of chemotherapy patients laboratory tests ${ }^{(17)}$, but provide no further clarifications on the use of this information in clinical practice. In the research context, nurses can autonomously decide on whether to apply the antineoplastic drugs or not, based on the laboratory results.

Based on the same results, neutropenia can be identified, which is one of the side effects of chemotherapy that indicates infection risk ${ }^{(24-25)}$ and orients nurses to start the clinical pathway for febrile neutropenia or perform screening. Studies have demonstrated the effective reduction of infection risks when nursing care pathways are employed in oncology practice(24). At the same time as neutropenia is identified, patient and family education actions are undertaken that emphasize preliminary knowledge on signs and symptoms and orientation about infection risks.

An Australian study at an Oncologic Hematology Center showed it, on a list of ten activities, clinical assessment was considered the most frequent, while patient/family counseling and education consumed most of the time ${ }^{(13)}$. In practice, these activities can be compared to the intervention "critical path development" in the present study, which also results in the start of clinical pathways and educative actions.

The main study results demonstrated the predominance of activities centered on antineoplastic 
treatment, due to the expected adverse effects of these drugs. No activities were found in the "family" and "community" domains, as described in the NIC.

Although the participating nurses validated the instrument contents, it is important to highlight that a further pre-test is needed before it can be applied to measure the workload, which is a subsequent research phase. Its contribution to cancer nursing, however, relates to the lack of CTC activity mapping in standardized language to orient the work process in this specialty and future research on the theme.

\section{Conclusion}

This study permitted the identification and validation of 48 activities Chemotherapy Center nurses accomplish during the care process.

Activity mapping helps to define nurses' role at chemotherapy outpatient clinics, so as to redesign the work process and eliminate activities that do not add value to the client. The identification of activities helps to measure the time consumed in nursing work and allows for the determination of the team workload and productivity.

\section{Acknowledgements}

The authors thank the Fundação Pio XII - Hospital do Câncer de Barretos and the nurses from the Chemotherapy Central for their receptiveness, welcoming and support during the course of the research.

\section{References}

1. O'Brien-Pallas L, Thomson D, Hall LM, Pink G, Kerr M, Wang $S$, et al. Evidence-based Standards for mensuring nurse staffing and performance. Otawa, Ontário: Canadian Health Services Reserch Foudation; 2004.

2. Gaidzinski RR, Fugulin FMT, Castilho V. Dimensionamento de pessoal de enfermagem em instituições hospitalares de saúde. In: Kurcgante $P$, coordenadora. Gerenciamento em enfermagem. $2^{a}$ ed. Rio de Janeiro: Guanabara Koogan; 2012. p. 121-35.

3. Pelletier D, Duffield C. Work sampling: valuable methodology to define nursing practice patterns. Nurs Health Sci. 2003;5(1):31-8.

4. Dochterman JM, Bulechek GM. Classificação das intervenções de enfermagem (NIC). $4^{a}$ ed. Porto Alegre: Artmed; 2008.

5. Gran-Moravec MB, Hughes CM. Nursing time allocation and other considerations for staffing. Nurs Health Sci. $2005 ; 7(2): 126-33$.
6. Mello MC. Carga de trabalho de enfermagem: indicadores de tempo em unidades de clínica médica, cirúrgica e terapia intensiva adulto [tese de doutorado]. São Paulo: Escola de Enfermagem da Universidade de São Paulo; 2011.

7. Costa RA, Shimizu HE. Atividades desenvolvidas pelos enfermeiros nas unidades de internação de um hospital escola. Rev. Latino-Am. Enfermagem. 2005;13(5):654-62.

8. Chaboyer W, Wallis M, Duffield C, Courtney $M$, Seaton $\mathrm{P}$, Holzhauser $\mathrm{K}$, et al. A comparison of activities undertaken by enrolled and registerd nurses on medical wards in Australia: an observational study. Int J Nurs Stud. 2008;45(9):1274-84.

9. Bordin LC, Fugulin FMT. Distribuição do tempo das enfermeiras: identificação e análise em Unidade MédicoCirúrgica. Rev Esc Enferm USP. 2009;43(4):833-40.

10. Soares AV, Gaidzinski RR, Cirico MV. Identificação da intervenções de enfermagem no sistema de alojamento conjunto. Rev Esc Enferm USP. 2010;44(2):308-17.

11. Garcia EA, Fugulin FMT. Distribuição do tempo de trabalho das enfermeiras em Unidade de Emergência. Rev Esc Enferm USP. 2010;44(4):1032-8.

12. De Cordova PB, Lucero RJ, Hyun S, Quinlan P, Price K, Stone PW. Using the nursing interventions classification as a potential measure of nurse workload. J Nurs Care Qual. 2010;25(1):39-45.

13. Blay N, Cairns J, Chisholm J, O'baugh J. Research into the workload and roles of oncology nurses within an outpatient oncology unit. Eur J Oncol Nurs. 2002;6(1):6-12.

14. Medvec BR. Productivity and workload mensurement in ambulatory oncology. Sem Oncol. 1994;10(4):288-95. 15. Polit DF, Beck CT. Fundamentos de pesquisa em enfermagem. 7a ed. Porto Alegre: Artmed; 2011.

16. Hurst K. Selecting and applying methods for estimating the size and mix of nursing teams. [internet]. Leeds (UK): Nuffield Institute for Health; 2003. [acesso 6 abr 2008]. Disponível em: http://www.who.int/hrh/ tools/size_mix.pdf

17. Quinn A. Expanding the role of the oncology nurse. Biomed Imaging Interv J. 2008;4(3):e34.

18. Conselho Federal de Enfermagem (BR). Legislação. Resolução COFEN-210/1998. Dispõe sobre a atuação dos profissionais de Enfermagem que trabalham com quimioterápico antineoplásicos [Internet]. Brasília (DF): Cofen; 2011 [acesso 25 mar 2011]. Disponível em: http://site.portalcofen.gov.br/node/4257.

19. Ministério da Saúde (BR). Instituto Nacional de Câncer. Ações de enfermagem para o controle do câncer: 
uma proposta de integração ensino-serviço [Internet]. Brasília (DF): Ministério da Saúde; 2008 [acesso 22 mar 2012]. Disponível em: http://www1.inca.gov.br/ enfermagem/index.asp

20. Sauerland C, Engelking C, Wickham R, Corbi D. Vesicant extravasation part I: Mechanisms, pathogenesis, and nursing care to reduce risk. Oncol Nurs Forum. 2006;33(6):1134-41.

21. Chaves DC, Dias CG, Gutiérrez MGR. Extravasamento de drogas antineoplásicas em Pediatria: algoritmos para a Prevenção, tratamento e seguimento. Rev Bras Cancerol. 2008;54(3):263-73.

22. Brunherotti MR. Intervenção no extravasamento de quimioterápicos vesicantes: revisão integrative da literature [dissertação de mestrado]. Ribeirão Preto (SP): Escola de Enfermagem de Ribeirão Preto da Universidade de São Paulo; 2007.

23. Gutiérrez MGR, Adami NP, Castro RAP, Fonseca SM. Natureza e classificação das intervenções de enfermagem em ambulatório de quimioterapia de adultos. Rev. Latino-Am. Enfermagem. 2000;8(3):33-9. 24. Sanhudo NF, Moreira MC, Carvalho V. Tendências da produção do conhecimento de enfermagem no controle de infecção em oncologia. Rev Gauch Enferm. 2011;32(2):402-10.

25. Cataneo C, Canini SRMS, Oliveira e Castro PT, Hayashida M, Gir E. Avaliação da sensibilidade e da especificidade dos critérios para isolamento de pacientes admitidos em um hospital especializado em oncologia. Rev. Latino-Am. Enfermagem. [periódico na Internet]. set-out 2011 [acesso 2 out 2012];19(5):1072-9. Disponível em: http://www.scielo.br/pdf/rlae/v19n5/ pt_03.pdf 